\title{
EUCALYPTUS STAND SAMPLE PLOTS COMPARED: FIXED AREA AND FIXED NUMBER OF TREES ${ }^{1}$
}

\author{
Danilo Roberti Alves de Almeida ${ }^{2 *}$, Helio Garcia Leite ${ }^{3}$ and Eric Bastos Gorgens ${ }^{4}$
}

\footnotetext{
${ }^{1}$ Received on 16.04.2014 accepted for publication on 03.03.2016.

${ }^{2}$ Escola Superior de Agricultura "Luiz de Queiroz" (ESALQ/USP), Programa de Pós graduação em Recursos Florestais, Piracicaba, SP - Brasil. E-mail: <daniloflorestas@gmail.com>.

${ }^{3}$ Universidade Federal de Viçosa, Centro de Ciências Agrárias, Viçosa, MG - Brasil. E-mail: <hgleite@gmail.com>.

${ }^{4}$ Universidade Federal dos Vales do Jequitinhonha e Mucuri, Departamento de Engenharia Florestal, Diamantina, MG - Brasil. E-mail:<e.gorgens@gmail.com>.

*Corresponding author.
}

\begin{abstract}
This study compares sampling methods based on plots of fixed area and based on a fixed number of trees. The study was conducted in a Eucalyptus forest surveyed using three plot types: rectangular with fixed area, circular with fixed area and fixed number of trees. The estimation accuracies were evaluated for the average diameter per plot and for the number of stems, the basal area and the volume per plot. The null hypothesis of equality between the sampling methods was assessed by t-test. No significant differences were found between the three sampling methods.
\end{abstract}

Keywords: Plots; Forest inventory; Methodology.

\section{AMOSTRAGEM COM PARCELAS DE ÁREA FIXA E DE ÁREA DEFINIDA PELO NÚMERO DE COVAS EM UM POVOAMENTO DE EUCALIPTO}

\begin{abstract}
RESUMO - No presente trabalho foram comparados métodos de amostragem de área fixa (com parcelas retangular e circular), com amostragem em parcelas definidas por um número fixo de covas. O estudo foi realizado em um povoamento de Eucalipto, inventariado empregando os três tipos de parcela, assumindo um erro de amostragem máximo de 10\%, a 95\% de probabilidade. Foram avaliadas a precisão das estimativas de diâmetro médio, número de fustes, área basal e volume por hectare. A hipótese de igualdade entre as estimativas obtidas foi avaliada empregando o teste $t$, em nivel de $5 \%$ de significância. Não foram verificadas diferenças significativas entre as estimativas obtidas pelos diferentes métodos de amostragem.
\end{abstract}

Palavras-chave: Inventário; Floresta; Metodologia.

\section{INTRODUCTION}

Eucalyptus plantations provide for the growing demand of charcoal for coking, of cellulose for paper, and of wood, among others. Rapid growth and high production of these forests supply market demands and allow a good financial return, but also contribute to the loss of native forests. Due to the cost and long return cycles of forestry projects, it is necessary to employ efficient sampling methods when estimating production. Precise and accurate information allows better decision-making regarding silvicultural treatments, management, planning and market options. Forest inventories are indispensable for monitoring production, providing qualitative and quantitative information (SOARES et al., 2006).

A forest inventory is based on field measurements of trees' attributes, such as total height (Ht) and diameter at breast height of $1.3 \mathrm{~m}(\mathrm{DBH})$, among other quantitative and qualitative variables. If all trees are measured within the stand or population, the technique is referred as $100 \%$ inventory, or census (SOARES et al., 2006). Census over large areas is, however, impractical (SOUZA, 1981).

Revista Árvore, Viçosa-MG, v.40, n.3, p.529-533, 2016 http://dx.doi.org/10.1590/0100-67622016000300016 
In practice, forest inventories employ plot-based sampling. These allow estimation (mean with confidence interval) of the true mean of a population or stand, for any attribute of interest, such as timber volume per hectare, biomass per hectare, stems per hectare, basal area per hectare, mean height of the dominant trees and mean stem diameter for all stems in a DBH class (SCOLFORO, 1993).

The plots (sample units) may have fixed or variable areas and the plot shape can be square, rectangular or circular (SOARES et al., 2006). The size and the number of sample units must be sufficient to represent the trees, but small enough not to consume much time during installation and data collecting (SCHEUDER et al., 1993). Sampling techniques should be conducted aiming to reduce both bias and the width of the confidence interval of the estimated attribute as much as possible, yet minimize the amount of work and consequently cost. Inventory cost is directly proportional to the labor intensity. Accuracy depends on the stand's variability, being expressed by the relative sampling error. The accuracy is also affected by the precision of attribute measurement (some of which are obtained indirectly) and by any bias inherent in a method (SOUZA, 1981).

Bias, or systematic distortion of an estimate, can be caused by measurement methods, by sampling methods or by the estimation techniques (FREESE, 1962). Apart of the shape or the size of the sample units will be possible to estimate the volume of a population or a stand without systematic errors (HUSCH, 1971). The efficiency of different sampling methods (shape and size of plots) depends on factors such as forest conditions (spacing, age, management) and the type of relief, among other things (NAKAJIMA et al., 1998).

When the plot has fixed area, it is common to define the length and width of a rectangle (or radius of a circle), making the necessary corrections to the slope (CAMPOS; LEITE, 2013). Plot size of rectangles is determined by the average distance between a predetermined number of rows of trees, so may result in imperfect rectangles.

The objective of this study was to evaluate three different sampling methods: fixed area with rectangular plot (12 $\mathrm{m} \mathrm{x} 15 \mathrm{~m}$ ), fixed area with circular plot (radius of $8 \mathrm{~m}$ ) and plot with a fixed number of 30 trees ( 5 rows of six trees each).

\section{MATERIALAND METHODS}

\subsection{Field Site}

The study was conducted in a Eucalyptus plantation at Ponte Nova municipality, Minas Gerais state in Brazil $\left(20^{\circ} 52^{\prime} 56.52 \mathrm{~S}, 42^{\circ} 28^{\prime} 42.97 \mathrm{~W}\right)$. The forest stand had approximately 40 hectares; the trees were spaced 3 $\mathrm{x} 2 \mathrm{~m}$ and were seven years old at the measuring time. The climate is tropical with higher rainfall during the austral summer. The average annual temperature is $21^{\circ} \mathrm{C}$, and the annual rainfall is $1.300 \mathrm{~mm}$.

\section{Installation of the plots, measurements and data processing}

Three alternatives setups were used for the sample units:

- Fixed area and rectangular plot - $12 \mathrm{~m}$ x $15 \mathrm{~m}$

- Fixed area and circular plot - radius of 8 meters

- Fixed number of trees - 5 rows of 6 trees each

The fixed area plots were delimitated by painting the border trees. For the plots with a fixed number of trees, 30 trees distributed in 5 rows were measured. The dimensions of each plot were obtained by the average length of the five rows (length) and the average distance between the two pairs of corner trees (width). The two long axes' lengths were measured from the first to the seventh tree. Dead trees and planting failures were also considered as an individual. The circumference of all the trees within the plot was measured with a tape and later transformed to DBH. Heights were obtained only for the six trees in the first line of each plot, using a Vertex hypsometer. The other tree heights were estimated from their $\mathrm{DBH}$, using a hypsometric model adjusted to measured data from 298 trees randomly distributed across the stand:

$$
\operatorname{Ln}(H t)=\beta_{0}+\beta_{1} * 1 / D B H+\varepsilon
$$

Volume of each tree was obtained from equation (2) as suggested by Campos and Leite (2009):

$$
\begin{gathered}
\operatorname{Ln}(V)=-11,11036+3,60867 \operatorname{Ln} D B H+ \\
\\
0,15334 \operatorname{Ln} H t ; R^{2}=0,921
\end{gathered}
$$




\subsection{Statistical Analysis}

The average $\mathrm{DBH}$, the average $\mathrm{Ht}$, the number of stems, the basal area and the volume of each plot were obtained for 30 plots for each of the three methods of plot setup. Units were normalized to a per hectare basis and the three means for each attribute were then compared in pairs, using the t-test with $95 \%$ of confidence level.

\section{RESULTS}

The best linear fit hypsometric equation obtained to estimate height from DBH was:

$$
\operatorname{Ln}(H t)=3,829-8,67 * 1 / D B H ; R^{2}=0,57
$$

The residual standard error to estimate the $\mathrm{Ht}$ was 1.99 and the coefficient of variation was $7.9 \%$ (Figure 1).

The biggest differences observed between two means $(n=30)$ for the three sampling alternatives were related to number of stems, diameter, basal area and volume. These means differences were, respectively, 31 stems per ha, $0.08 \mathrm{~cm}$ of $\mathrm{DBH}, 0.7$ $\mathrm{m}^{2} /$ ha of basal area and $7.61 \mathrm{~m}^{3} /$ ha of volume. However, by t-test, none of these differences were significant (Figure 2).

The stand estimated volume for the 40 ha, based on the samples of fixed area with rectangular shape, was $9746 \mathrm{~m}^{3}+/-7.6 \%$ (95\% confidence level) (Table 1).

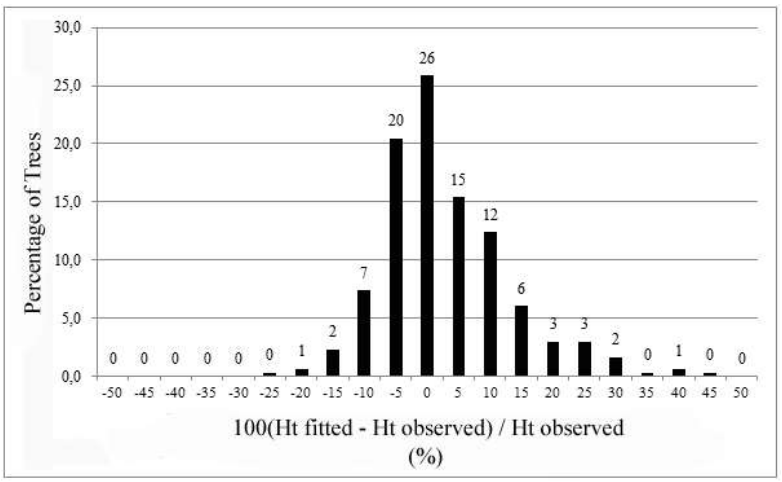

Figure 1 - Frequency distribution of the trees among errorof-estimate classes.

Figura 1-Percentagem de árvores por classe de erro percentual das estimativas de altura total.
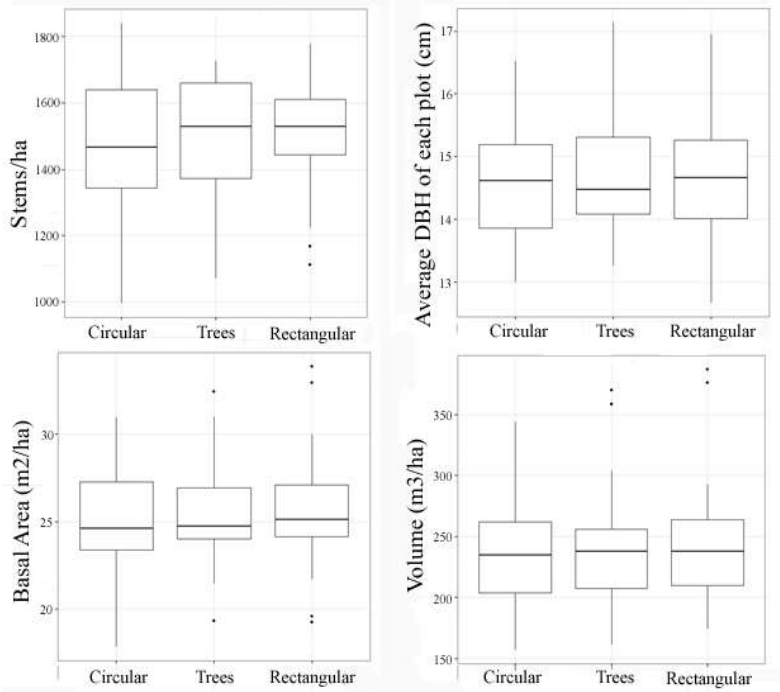

Figure 2 - Boxplots with $1^{\text {st }}$ and $3^{\text {rd }}$ quartiles, comparing number of stems, mean diameter, basal area and volume between three sampling alternatives. "Circular" means sampling strategy had fixed area and circular shape. "Trees" means sampling strategy had fixed number of trees. "Rectangular" means sampling strategy had fixed area and fixed rectangular shape.

Figura 2-Gráfico de boxplot para o número de fustes, diâmetro médio, área basal e volume por hectare comparando as três metodologia estudadas. O gráfico apresenta a mediana, $1^{\circ}$ e $3^{\circ}$ quartil e $1.5 *$ distância interquartil.

Table 1 - Stand volume ( 40 hectares) and the sampling error $(95 \% \mathrm{CI})$ for each sampling setup. "Circular" means sampling strategy had fixed area and circular shape. "Trees" means sampling strategy had fixed number of trees. "Rectangular" means sampling strategy had fixed area and fixed rectangular shape.

Tabela 1 - Volume total da área de estudo (40 hectares) e o erro de amostragem para probabilidade de 95\% por método investigado.

\begin{tabular}{lccc}
\hline & Circular & Rectangular & Trees \\
\hline Total volume & 9,442 & 9,746 & 9,585 \\
$\begin{array}{l}\text { Relative sampling } \\
\text { error (\%) }\end{array}$ & \pm 7.1 & \pm 7.6 & \pm 6.8 \\
\hline
\end{tabular}

\section{DISCUSSION}

The bigger the plot area, for a fixed number of plots, the narrower the error bar on the estimate of an attribute's true mean value in a population or stand. Small plots increase the coefficient of variation, increasing the inventory error. However large plots are labor and

Revista Árvore, Viçosa-MG, v.40, n.3, p.529-533, 2016

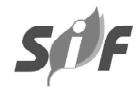


Table 2 - P-values for the nine t-test comparisons between three sample setups.

Tabela 2 -P-valor do teste $t$ de Student comparando parcelas: retangulares de área fixa, circulares de área fixa e fixas quanto ao número fixo de covas.

\begin{tabular}{lccc}
\hline & Circular x Trees & Circular x Rectangular & TreesxRectangular \\
\hline Number of Stems & $0.86^{\mathrm{ns}}$ & $0.54^{\mathrm{ns}}$ & $0.64^{\mathrm{ns}}$ \\
Basal Area $\left(\mathrm{m}^{2}\right)$ & $0.65^{\mathrm{ns}}$ & $0.40^{\mathrm{ns}}$ & $0.63^{\mathrm{ns}}$ \\
Average Diameter $(\mathrm{cm})$ & $0.77^{\mathrm{ns}}$ & $0.84^{\mathrm{ns}}$ & $0.93^{\mathrm{ns}}$ \\
Volume $\left(\mathrm{m}^{3}\right)$ & $0.75^{\mathrm{ns}}$ & $0.53^{\mathrm{ns}}$ & $0.74^{\mathrm{ns}}$ \\
\hline
\end{tabular}

ns - no significant difference

ns - diferença não significativa

cost intensive. The goal is to find a size that provides the optimal balance between time (cost) and error. ZEIDE (1980) proposed a methodology to determine the optimum plot size by minimizing the time required for location and measurement of trees for a given level of precision. In this work the chosen plot size (around $180 \mathrm{~m} 2$ ) was enough to achieve $90 \%$ of accuracy required by Brazilian law.

It is recommended to use rectangular plots when the terrain slope is greater than $10 \%$, improving the spatial variation representation. In flat areas, it is possible to use square plots without loose information. Smaller plots (ranging $100-400 \mathrm{~m} 2$ ) are expected to show high variability. For stands managed using thinning operations, plots of $500-600 \mathrm{~m} 2$ have been recommended (CAMPOS; LEITE, 2013).

The risk of using a fixed number of trees per sample is the variation in tree spacing. If this variation is ignored when normalizing to a per hectare basis, errors are incorporated. In the case of planted forests with homogeneous trees distribution, this risk is small. This methodology has been widely adopted due to the ease of implementation since the trees themselves define the limits of the sampling unit.

\section{CONCLUSION}

The results showed that the three methods studied provided similar results. Although having differet shapes, the areas of the plots were very similar, leading to a similar measurement effort across the three sampling setups. All three methods are efficient and practical, and the forest manager can safely choose the alternative of his preference.

Forest inventory with similar populations to this study can be conducted with the same efficiency using any of the three different plot designs: fixing the area (using both, circular shape and rectangular shape); and fixing the number of trees. However, in the case of using the variable area method (fixed number of trees), it is important to have homogeneous spacing of trees.

\section{ACKNOWLEDGEMENTS}

We thank the Sociedade de Investigações Florestais (SIF) for partial a fellowship, Dr. Bruce Walker Nelson for language checking and Braulio Pizziolo, João Pedro F. Lenz, Rafael L. Carneiro, Fernanda Franco, Felicio Oliveira and Guilherme L. Fernandes for help in the field inventory.

\section{REFERENCES}

CAMPOS, J.C.C.C.; LEITE, H.G. Mensuração florestal: perguntas e respostas. Viçosa, MG: Universidade Federal de Viçosa, 2009. P.648.

FREESE, F. Elementary forest sampling. Madison: USDA Forest Service, Forest Product Laboratory, 1962.91p (Agriculture Handbook, 232).

HUSCH, B. Planificacion de un inventário forestall. Roma: FAO, 1971. 135p. (Estudios de silvicultura y productos forestales).

NAKAJIMA, N.; KIRCHNER, F.; SANQUETTA, C.; POSONSKI, M. Elaboração de um sistema de amostragem para estimativa de valores correntes e mudança/crescimento em reflorestamento de Pinus. Curitiba: CNPq/ UFPR, 1998.

PEREIRA, A.J. Emprego do método Bitterlich em inventários florestais e em modelagem do crescimento e da produção. Dissertação (Mestrado em Ciência Florestal) - Universidade Federal de Viçosa, Viçosa, MG: 2002. 
SCOLFORO, J.R. Inventário florestal. Lavras, MG: Universidade Federal de Lavras, 1993. 228p.

SCHEUDER, H.T.; GREGOIRE, T.G.; WOOD, G.B. Sampling methods for multire-source forest inventory. New York: John Wiley; 1993. $446 \mathrm{p}$.

SCHUMACHER, F.X.; HALL, F.S. Logaritmic expression of timber volume. Journal of Agricultural Research, v.47, n.9, p.719-734, 1933.

SOARES, C.P.B.; PAULA NETO, F.; SOUZA, A.L. Dendrometria e inventário florestal.
Viçosa, MG: Universidade Federal de Viçosa, 2006. 276p.

SOUZA, A.L. Comparação de tipos de amostragens, com parcelas circulares de área fixa e variável, em povoamentos de Eucalyptus grandis de origem híbrida, cultivados na região de Bom Despacho, Minas Gerais. 1981. 97f. Dissertação (Mestrado em Ciência Florestal) - Universidade Federal de Viçosa, Viçosa, MG, 1981.

ZEIDE, B. Plot size optimization. Forest Science, v.26, p.251-257, 1980. 